Max-Planck-Institut für demografische Forschung

Max Planck Institute for Demographic Research

Konrad-Zuse-Strasse 1 - D-18057 Rostock - GERMANY

Tel +49 (0) 3812081 - 0; Fax +49 (0) 3812081 - 202;

http://www.demogr.mpg.de

MPIDR WORKING PAPER WP 2012-005

JANUARY 2012

\title{
Spatial Aspects of the Rise of Nonmarital Fertility across Europe since 1960: The role of states and regions in shaping patterns of change
}

Sebastian Klüsener (kluesener@demogr.mpg.de)

Brienna Perelli-Harris

Nora Sánchez Gassen (sanchez@demogr.mpg.de)

This working paper has been approved for release by: Mikołaj Szołtysek (szoltysek@demogr.mpg.de), Deputy Head of the Laboratory of Historical Demography.

(C) Copyright is held by the authors.

Working papers of the Max Planck Institute for Demographic Research receive only limited review. Views or opinions expressed in working papers are attributable to the authors and do not necessarily reflect those of the Institute. 
Spatial Aspects of the Rise of Nonmarital Fertility across Europe since 1960: The role of states and regions in shaping patterns of change

Sebastian Klüsener ${ }^{\ddagger}$, Brienna Perelli-Harris ${ }^{\ddagger}$, Nora Sánchez Gassen ${ }^{\ddagger}$

\$ Max Planck Institute for Demographic Research

$\$$ University of Southampton 


\begin{abstract}
This paper investigates the role of states and regions in shaping spatial patterns of nonmarital fertility in Europe since 1960 using a dataset of 497 European subnational regions and smaller countries. Almost all regions registered substantial nonmarital fertility increases over the last 50 years. Prior research by Watkins (1991) has shown that in the first half of the $20^{\text {th }}$ century states played a dominant role in drawing the demographic map of Europe. As a result, subnational regional variation decreased, while differences between countries increased. In this paper, we investigate whether states continue to play such a dominant role in delineating patterns of nonmarital fertility between 1960 and 2007. We find that variation in nonmarital fertility levels increased as a whole across Europe, and states continued to be important for determining these patterns. However, the role of states relative to regions declined in the latest period examined (1990 and 2007). Possible explanations for the changes include increased supranational integration, for example within the European Union, and decentralisation within states leading to increases in variation in subnational contextual conditions.
\end{abstract}

\title{
Acknowledgements
}

We kindly thank Jean-Michel Decroly for giving us access to his data collection from the Atlas de la Population Européenne-project (Decroly and Vanlaer 1991). Furthermore, we would like to thank Anne Hiller for her work on the MPIDR Population History GIS Collection. Gratitude is also expressed to Hilde Bras, Sandra Krapf and members of the Nonmarital Fertility network for comments on earlier versions of this paper. In addition, we would like to thank Sigrid Gellers-Barkmann for her data support. 


\section{Nonmarital Fertility Trends across Time and Space ${ }^{1}$}

Processes of demographic change usually do not occur randomly in space and time, but are influenced by differences in the compositional characteristics of populations and prevailing contextual conditions (Coale and Watkins 1986; Lesthaeghe 1980). Previous studies have shown that regional and state borders can be very important for spatially defining demographic processes as they can constitute strong geographic divides in terms of jurisdiction, cultural and socio-economic conditions (Watkins 1991; Decroly and Grasland 1993; Bocquet-Appel and Jakobi 1996; Lesthaeghe and Neels 2002; Lesthaeghe and Neidert 2006). One of the most influential studies of the spatial distribution of demographic events was the Princeton European fertility project, which examined how changes in fertility and nuptiality varied by regions and countries during the demographic transition (Coale and Watkins 1986).

As part of this project, Susan Watkins $(1990 ; 1991)$ found that the variation in regional nonmarital fertility rates (as well as nuptiality and marital fertility rates) decreased between 1870 and 1960 across Western Europe, but that this decline in variation occurred mainly within states. By 1960, levels of fertility and nuptiality among subnational regions of the same country had become very similar, while stark differences had emerged between states. However, Watkins concluded by predicting that European nation states would lose importance in shaping conditions for demographic behaviour as a result of supranational European integration. As a consequence, she expected that "in the future

\footnotetext{
${ }^{1}$ The maps used in this publication are partly based on the following source: ( EuroGeographics for the administrative boundaries.
} 
national boundaries will become less deeply etched on the demographic map of western Europe. [...] I expect that national differences will persist as shadings of tone if not of color" (Watkins 1991: 180). In an article published in 1990, she explicitly refers to the period after 1992 (Watkins 1990: 265).

In this paper, we use a spatial dataset of 497 (subnational) regional units of timeconstant area to examine how states ${ }^{2}$ and regions ${ }^{3}$ shape spatial patterns of nonmarital fertility across Europe from 1960 to 2007. Using spatial analysis methods, we test Watkins' expectation that after 1990 states would remain relevant, but would become less dominant in shaping demographic behaviour (1990: 265). Watkins' analysis focuses on a period of time in which the political geography of Europe was dominated by (nation) states and empires (1870-1960). This has changed in recent decades. Since 1960, supranational institutions, particularly the European Union, have become more important (Held and McGrew 1993) and may have decreased differences across states (and regions). The financial and social integration of Europe may have reduced between-country (and within-country) variation in contextual conditions. At the same time, many states

\footnotetext{
${ }^{2}$ When we refer to states in this paper, we mean sovereign states as e.g. defined in the first article of the Montevideo Convention. This definition does not include federated states such as the German Länder or the Belgium regions. When talking about the national, supranational or subnational level, this is done in reference to sovereign states, also including those which are not dominated by one single nation.

${ }^{3}$ When we refer to regions in this paper, we mean subnational regions within European states. In Watkins' publications these were called provinces.
} 
have undergone processes of decentralisation, which might have weakened the dominance of state-level institutions in favour of subnational ones, such as regional or local governments. This process of decentralisation has potentially increased subnational variation in contextual conditions. Both of these processes may have weakened the role of national level structures and processes in shaping geographic patterns of demographic behaviour.

Nonmarital fertility is a particularly interesting behaviour to analyze, because nearly every country in Europe has experienced sharp increases in nonmarital fertility over the past few decades. Nonetheless, levels of nonmarital fertility continue to vary substantially across countries (Eurostat 2011, Perelli-Harris et al. forthcoming). In addition, nonmarital fertility varies within countries, with strong regional differences, e.g. between eastern and western Germany, or northern and southern Italy (see Fig. 1d). Although other studies have examined how spatial patterns of nonmarital fertility have varied across time (Decroly and Vanlaer 1991, Kok 2009, Lesthaeghe and Neels 2002), none has explicitly examined to what extent the spatial pattern of the recent increases in nonmarital fertility are related to the political geography of Europe using subnational regional data. To test Watkins' predictions (1990: 246; 267), we employ two approaches to evaluate the relevance of states, regions and their borders. First, we use an inequality measure to investigate what proportion of the overall regional variation in nonmarital fertility can be attributed to between- and to within-country differences, and how this changes over time. Second, we compare the role of state borders relative to subnational regional borders in shaping spatial pattern of nonmarital fertility. In this way, we are able 
to assess to what extent structures and processes with a national level-dimension have shaped spatial nonmarital fertility trends in Europe over the last 50 years.

\subsection{The increase and variation in nonmarital fertility across Europe}

In 1960, nonmarital fertility in Europe was relatively rare; few countries had more than $10 \%$ of births outside of marriage, while none reported levels above $30 \%$. By 2007 , however, only a small number of countries reported fewer than $10 \%$ of births outside of marriage, and approximately half of all countries had levels above 30\% (Eurostat 2011; Statistical Offices). In addition, the spatial variation in nonmarital fertility across Europe remains stark. In 2007, most countries of Northern Europe had over 50\% of births occurred to unmarried mothers, while in some parts of Southeastern Europe, the percent of births outside of marriage remained below $10 \%$, for example in Greece. The variation in nonmarital fertility does not necessarily spread gradually across the continent; instead there can be distinct differences between neighbouring countries, for example between Greece and Bulgaria, where the latter had $50 \%$ of all births outside of marriage.

Besides diversity across countries, substantial variation exists within countries. In Germany, for example, $25 \%$ of births occurred outside of marriage in the western regions in 2007 , while $57 \%$ of births were to unmarried mothers in the eastern regions (Klüsener and Kreyenfeld 2009). Sometimes levels of nonmarital childbearing are less likely to be similar in regions within countries but rather extend over borders into regions of neighbouring countries. For example southeastern Poland reported around $10 \%$ of the births as 
nonmarital -- very similar to levels reported in adjacent western Ukraine and western Belarus -- but northwestern Poland registered around 35\% of all births to unmarried women (see Fig. 1d). Thus, the distribution of nonmarital fertility across Europe looks like a patchwork blanket, with some patches circumscribed by national borders, and others defined by regions.

The factors leading to the increase and variation in nonmarital fertility across Europe since the 1960s are complex and multi-faceted (Perelli-Harris et al. 2010; Kok 2009; Kiernan 2004; Lesthaeghe 2010; Thornton and Philipov 2009). One of the most important reasons for the rise in nonmarital fertility has been the increase in cohabitation; most births outside of marriage now occur within co-residential relationships that are not officially registered (Perelli-Harris et al. 2010; Perelli-Harris et al forthcoming). While in earlier periods most couples married before the birth of the first child, now many couples either postpone marriage to later stages in the life course or remain unmarried. Thus, the increase in nonmarital fertility can be directly attributed to the decline in the institution of marriage and its replacement with cohabitation. In this paper, we do not address all reasons for cross-national variation in family formation behaviour; nonetheless, it is important to realize that while some populations have experienced an increase in alternative family forms, others have clung to family systems that have so far suppressed the emergence of new family behaviours (Reher 1998; Heady and Kohli 2010; Lesthaeghe 2010). 


\subsection{The role of states.}

Previous research has shown that in the $19^{\text {th }}$ and $20^{\text {th }}$ centuries, states were important for organizing and structuring populations (Watkins 1991; Lefebvre 1991). The development of the modern state led to the establishment of a number of institutions which facilitated economic and social interactions and the enforcement of harmonised legal norms within the territories of these states (Decroly and Grasland 1993; Lefebvre 1991). For example, most countries established state-wide education systems, which were usually characterized by standardized curricula. Typically, the most prevalent language was privileged, thereby increasing linguistic homogeneity (Watkins 1991). Improvements in the communication and transport infrastructure fostered the emergence of state-wide mass media, which spread values and ideas from the urban centres into the peripheral regions of the countries (Watkins 1991). As a result of these developments, communication and the circulation of ideas and social norms has usually been denser within states than across states. This has also had implications for knowledge about changes in demographic behaviour, which often spread faster within states than across state borders (Decroly and Grasland 1993).

European countries also enacted laws and policies related to the institution of marriage and children born outside of marriage. Although some countries, such as Yugoslavia in the 1970s and 1980s (Šarčević 1981) and Spain (González Beilfuss 2005) have allowed regions to dictate their own family law, most countries developed a legal approach that was standardized across subnational regions. The legal instruments may have promoted marriage or alternatively supported cohabitation across a range of policy di- 
mensions, such as inheritance law or laws regulating the division of property upon dissolution or divorce, as well as laws regulating the establishment of paternity and joint custody for unmarried fathers (Perelli-Harris and Sánchez Gassen 2010). Changes were partly enacted to protect vulnerable individuals and provide equal rights to fathers, but also by fiscal interests to reduce the costs of supporting lone mothers (Krause 1976).

European countries have been developing state-wide welfare systems since the late $19^{\text {th }}$ century, aiming to alleviate poverty and support those in need. Nonmarital children and their parents may have directly profited from the social security systems, insurance and pension schemes that were developed in this process. For instance, some states introduced financial or housing assistance to single mothers that may have led to an increase in nonmarital childbearing (see also Perelli-Harris and Sánchez Gassen 2010). In the long term, the development of the welfare state may also have reduced individuals' reliance on kinship networks and the church as providers of social security and assistance, also referred to as defamilisation or decommodification (McLaughlin and Glendinning 1994; Esping-Andersen 1999). The degree of defamilisation differs across states, as can be observed in the variation in instruments and levels of support for individuals and families (Esping-Andersen 1999). These state institutions may have allowed women to become less reliant on the institution of marriage and instead more willing to have children outside of marriage.

In general, the modern state created an environment in which people located within its borders grew to have more similar cultural ideas and family behaviours. State policies helped to demarcate political state borders by reinforcing social, cultural, eco- 
nomic and or political conditions (Decroly and Grasland 1993). This resulted in convergence processes within the territories, with implications for spatial patterns of demographic behaviour.

It is also important to recognise that over our study period some regional borders have been turned into state borders (e.g. in former Yugoslavia), and vice versa (unification of Germany). In fact, state borders may be redefined based on ethnic or cultural identities which practice certain family behaviours. For example, the breakup of Yugoslavia into independent republics may have resulted in a closer match between state borders and family behaviours. Thus, cultural practices which are also reflected in family behaviours may be one of the factors leading to the development of new nation states throughout the late $20^{\text {th }}$ century.

\subsection{The role of regions.}

Despite the dominant role of the nation state in shaping demographic behaviour, especially in the late $19^{\text {th }}$ and the first half of the $20^{\text {th }}$ century, regional variation within countries has continued to be substantial. Studies have found great distinctions in fertility and nuptiality behaviour in northern and southern Italy (Castiglioni and Dalla Zuanna 2009: 5), eastern and western Germany (Klüsener and Kreyenfeld 2009), or the Flemish and the Walloon parts of Belgium (Lesthaeghe and Neels 2002). Some countries have pockets of historically high levels of nonmarital fertility, for example, southern Portugal, where nonmarital childbearing often occurred within cohabitation, with many parents marrying after the birth of their children (Livi-Bacci 1971). Thus, regions may define dis- 
tinct variation in behaviour, indicating that some regions have undergone substantial demographic and social change, while others have not (Lesthaeghe and Neidert 2006). Regional borders can demarcate socio-economic, ethnic or linguistic boundaries that may have profound effects on demographic behaviour. Certain behaviours and attitudes may remain distinct within regions, e.g. religious attitudes, cultural practices, or political orientation.

Also, states provide varying degrees of legislative power to their regions, depending on the level of political centralisation. While some countries such as France or Poland enact legislation and create policies at the national level, other countries such as the federal states of Germany and Switzerland give their regions substantial autonomy. The degree of legislative power held by national bodies also varies over time. Over the last decades Europe has witnessed a significant decentralisation process in a number of countries (e.g. Belgium, United Kingdom), potentially strengthening the role of regions in shaping patterns of demographic change, especially through policies or legislation. A particularly illustrative case is Spain, which granted its autonomous communities substantial sovereignty in the Post-Franco era. These regions have different rules governing the registration and legal consequences of cohabitation (González Beilfuss 2005).

\subsection{The role of supranational institutions.}

Developments at the supranational level may also have weakened the role of states and state borders in shaping demographic behaviour (for a general discussion see Agnew 
2008). Changes in media and communication have led to a greater exposure to alternative lifestyles. The spread of the internet has facilitated the distribution of news and information across borders (Di Maggio et al. 2001; Graham 1998). Knowledge about new social norms, ideas and values can today diffuse across state borders much faster than in the past, potentially weakening the role of state borders as social, cultural and demographic divides. This may be particularly true for the European Union, where a common market for goods, capital and labour has facilitated economic activities across state borders and fostered the exchange of norms and ideas.

Various supranational institutions have also created bodies of law on childbearing born outside of marriage. For example, the European Convention on Human Rights of 1950 and decisions by the European Human Rights Court based on this Charta (e.g. Marckx-decision, 1979; Zaunegger-decision, 2009) have been very influential in forcing states to eliminate discrimination against unmarried parents in their legislation (see also Coester 1993; Goldhaber 2007). Another relevant supranational initiative is the Convention on the Legal Status of Children born out of Wedlock (in force since 1978), which aims to improve the legal situation of children born to unmarried parents and has so far been ratified by 23 European countries.

This body of supranational European law created a momentum for policy change, such as the harmonisation of the rights of children born outside of marriage (see e.g. Goldhaber 2007). These developments may have decreased between-country differences in the legal context and fostered convergence in levels of nonmarital childbearing. On the other hand, within-country differences in nonmarital childbearing are probably less af- 
fected by policy harmonisation imposed by supranational institutions, as most European countries do not allow their subnational regions to have their own family legislation, though there are a number of exceptions (see above). As a result, regional differences in nonmarital fertility within countries are probably less influenced by supranational trends in policy harmonisation as these regional differences are rather stemming from variation in compositional characteristics of the population or regional socioeconomic conditions. Thus, although supranational institutions may lead to both between-country and withincountry convergence in regional nonmarital fertility variation across Europe, we believe that between-country differences are affected by it to a higher degree.

Interestingly, both the regional and the supranational level may have gained in relevance during the decades since Watkins' study. This might have had an impact on nonmarital fertility behaviour in Europe, potentially leading to a greater variation of behaviours across subnational regions, or, conversely, to a harmonisation of behaviours across borders. On the other hand, despite these trends at the supranational and regional levels, sovereign states continue to play an important role in shaping contextual conditions. Education systems, welfare state budgets and taxation policies are still to a large extent under the responsibility of the state governments. In our analysis we will explore to what extent this is also reflected in the spatial pattern of nonmarital fertility trends. 


\section{Data and Methods}

\subsection{Data}

In this paper we use official statistics to test how states, regions and their borders are relevant for understanding spatial patterns of nonmarital fertility in Europe. The birth data were collected by the state statistical offices of the countries observed. For the period 1960 to 1990 we primarily use data compiled by the collaborators of the Atlas de la Population Européenne-project (Decroly and Vanlaer 1991) and the Demographic Yearbooks of the Council of Europe (2005). We match the data to GIS-shapefiles from the MPIDR Population History GIS Collection.

To study nonmarital fertility, we use the nonmarital fertility ratio, which is defined as the number of nonmarital live births divided by the total number of live births. This measure is crude, neither allowing us to control for age structure nor differences in the number of married and unmarried women between regions or in a region over time. The data also do not show childbearing within cohabitation, and how this has changed in recent decades (Perelli-Harris et al. forthcoming). However, the nonmarital fertility ratio is available for 37 European countries and at the subnational regional level for these countries over the last 50 years. Thus, our data represents approximately $70 \%$ of Europe's population, which covers a substantial part of Europe's landmass. Due to a lack of (regional) data for all cross-sections, we are unable to analyze Andorra, Albania, Monaco, Romania, and Turkey as well as all former USSR countries with the exception of the 
Baltic States ${ }^{4}$. Nevertheless, we do present indicators for all these countries on the descriptive maps if data are available for a particular cross-section.

We analyze four cross-sections: 1960, 1975, 1990 and $2007^{5}$ (see Appendices 1 and 2 for details on the dataset). The year 1960 has been chosen, because 1) it marks the endpoint of Watkins' (1991) study; and 2) nonmarital fertility was at an all-time low in 1960 (Sprangers and Garssen 2003), commonly referred to as the Golden Age of Marriage. We look at 1975 , because it signifies the era when nonmarital fertility started to rapidly increase in many countries, with the exception of some areas of Northern Europe that had experienced increases starting in the mid-sixties (Sprangers and Garssen 2003). 1990 represents the beginning of the period of political, economic and social transition throughout Central-Eastern and Eastern Europe; this upheaval may have led to an increase in nonmarital births in this area (Thornton and Philipov 2009; Perelli-Harris and Gerber 2011). In the period after 1990, nonmarital fertility also began to increase in some Southern European areas (e.g. Spain, northern Italy). Finally, we examine 2007, because it was the last year when cross-sectional data was available for all European regions.

\footnotetext{
${ }^{4}$ The Baltic States are treated as one state in the period 1960 until 1990 and as separate ones in the cross-section of 2007.

${ }^{5}$ For some countries, for which data at these cross-sectional years was not available, we had to draw on data from preceding or succeeding years (see Appendix 2 for an overview over all deviations).
} 


\subsection{Creation of a Dataset with Regional Units of Time-Constant Area}

In spatial studies, the choice of geographic scale can have substantial implications for outcomes and interpretations. This issue is commonly referred to as the modifiable areal unit problem (Openshaw 1984). In Europe, the diversity of country sizes and administrative divisions poses a particular challenge for spatial analyses. The European Union NUTS-classification system, which is based on population size, is commonly used for geographic analyses, but analyses including subnational data can take place on any of three levels: NUTS-1 - comprising countries and regions with population between 3 million and 7 million; NUTS-2 - countries and regions with population between 800,000 and 3 million; and NUTS-3 - countries and regions between 150,000 and 800,000 inhabitants. However, a limitation of these NUTS-classifications is that they are neither clear cut $^{6}$ nor necessarily reflect long-standing administrative definitions within countries. In Switzerland, for example, the NUTS-3 level cantons are the most relevant subnational administrative units, while in Austria it is the NUTS-2 level Bundesländer. In an attempt to overcome these shortcomings, we followed the regional country divisions used by the European Princeton Fertility Project (Coale and Watkins 1986), which correspond partly to the NUTS-2- and partly to the NUTS-3-regions (see Appendix 1 for detailed informa-

\footnotetext{
${ }^{6}$ The population size of the 292 NUTS-2-regions (excluding Turkey), for example, ranged in 2007 from 26,923 to 11.6 Mio, with $24 \%$ of the regions having populations below the 800,000 threshold, used to differentiate between NUTS-2 and NUTS-3 regions.
} 
tion $)^{7}$. This specification most accurately reflects the long-standing administrative definitions existing within countries and facilitates the testing of Watkins' expectations.

An additional challenge is that some countries in our dataset altered their administrative regional divisions, either by implementing small border modifications or farreaching reforms ${ }^{8}$. For these countries, we were unable to reconstruct a time-constant regional division from the available data for some cross-sections. However, as some of our spatial analysis methods are sensitive to the total number of regions in the dataset, it was important for us to have a dataset available that was time-constant in the number and area of its units. To address this problem we used an areal interpolation procedure to derive estimates for cross-sections, in which the regional division of a country differs from the division used for the regions of time-constant area $^{9}$ (Goodchild and Lam 1980; Gregory

${ }^{7}$ We also run our calculations on the smaller NUTS-2-dataset, which delivered very similar findings. This assured us that our choice had no substantial effect on the results.

${ }^{8}$ In Poland, for example, the first-level administrative division changed from 22 regions prior to 1974 to 49 in the period 1975-1998, before it was reduced to 16 .

${ }^{9}$ The areal interpolation method we use was areal weighting (Goodchild and Lam 1980), which is based on the assumption, that the occurrence of marital and nonmarital births is constant across space within the source regions, for which we have data available. This is a strong assumption, as it is unlikely that the population is homogenously distributed across space, nor can we expect that the nonmarital birth ratio is constant across each source region. However, the potential error emerging from the estimation is largely dependent both on the geographic detail of the source regions, as well as the geographic detail of the target regions, for which the estimations are produced. The higher the geographic detail of the source regions in comparison to the target regions, the smaller is the potential error emerging from the estimation procedure. As we had for almost all countries for which we ap- 
et al. 2010). Countries affected by this were Denmark (2007), Finland (2007), Germany (West) (1960, 1975), Germany (East) (2007), Poland (1960, 1975, 1990), and United Kingdom (1960, 2007). The estimation errors emerging from this method might cause biases in our results by blurring cross-border differences. As a result, within-country differences and first-order cross-border differences across regional borders might be underemphasized. However, calculations on a reduced file only including countries without estimations produced similar results and gave us confidence that the estimation errors have no substantial effect on the general findings.

During the period of observation, not only regional borders changed, but also state borders, especially after the collapse of communism in 1990. German reunification dissolved the East German-West German state border, so that today it is just a regional border within Germany. The split up of Czechoslovakia, the USSR, and Yugoslavia on the other hand, resulted in a number of regional borders becoming state borders. All of these changes can affect our measures. Therefore, we differentiate between two configurations: the configuration of states prior to 1990 that includes 29 countries, and the configuration in 2007 with 37 countries. Both configurations include all 497 regions, allowing us to assess the extent to which state border changes influence the indicators.

plied estimations very detailed source data available, we decided not to use more complex estimation methods such as e.g. the EM algorithm (see Gregory 2002). In order to derive the estimates we apply a spatial intersection, where we intersect a GIS-polygon file with border and area information on the source regions with the one of the target regions (Goodchild and Lam 1980). With this we obtain a GIS-dataset with smallest common polygons (also called zones of intersections), which enable us to reconstruct the values for the target regions. 


\subsection{Methods}

Watkins specified two conceptions of how states and regions could be relevant for shaping patterns of nonmarital fertility (1990: 246; 267). The first focuses on the space inside national territories, contrasting within-country regional variation in nonmarital fertility with variation between countries. This approach treats space hierarchically (membership of region i in country c), but does not take the spatial proximity of countries and regions into account. We address this conceptualization in our state vs. region analysis. The second conceptualization focuses on the borders themselves. This approach, which contrasts state and regional borders and focuses on spatial contiguity, is covered in our border analysis.

\subsubsection{State vs. region analysis}

Because we are interested in testing whether states or regions are more salient for describing patterns of nonmarital fertility, we decompose the overall variation in nonmarital fertility in our dataset into between-country and within-country variation for each crosssection. By contrasting the results for the different cross-sections, we are able to see how the share of the overall variation which can be attributed to between-country variation changes over time. According to Watkins' expectation, this share of the between-country variation should decrease after 1990. 
We construct measures of inequality based on the Theil-index (Theil 1965), which is calculated as follows:

$$
T=\sum_{i=1}^{n} s_{i} \log \left(n s_{i}\right) \text { with } s_{i}=y_{i} / \sum_{i=1}^{n} y_{i}
$$

with y denoting the nonmarital fertility ratio in region $\mathrm{i}$ and $\mathrm{n}$ the total number of regions. It can range from 0 (no inequality/differences between regions) to $\log (\mathrm{n})$ (total inequality). This measure can be decomposed to assess how much of the differences observed between the regions can be attributed to between-country differences (dissimilarities between the means of the regional values derived for each country), and within-country differences (variation in the regions belonging to one country):

$$
\begin{aligned}
& T=\sum_{c=1}^{\omega} s_{c} \log \left(n / n_{c} s_{c}\right)+\sum_{c=1}^{\omega} s_{c} \sum_{i \in c} s_{i, c} \log \left(n_{c} s_{i, c}\right) \\
& \text { with } s_{c}=\sum_{i \in c} y_{i, c} / \sum_{i}^{n} y_{i} \text { and } s_{i, c}=y_{i, c} / \sum_{i=1}^{n_{c}} y_{i, c}
\end{aligned}
$$

where $\mathrm{n}_{\mathrm{c}}$ denotes the number of regional units in each country $\mathrm{c}$. This can be rewritten as:

$$
T=T_{B}+T_{W}
$$

where $T_{B}$ represents the between-country component of inequality, and $T_{W}$ denotes the within-country component. From this equation we derive the $R_{B}$ measure (Rey 2004: 294), which shows the share of variation attributed to between-country differences:

$$
R_{B}=T_{B} / T
$$


This measure is less mean dependent than the $T_{B}$ and $T_{W}$-measures, so that the results based on the nonmarital birth ratio and the marital birth ratio only differ marginally for the $\mathrm{R}_{\mathrm{B}}$ measure ${ }^{10}$. To assess to what extent national and regional processes influence the spatial pattern, we calculate $\mathrm{R}_{\mathrm{B}}$ for the two different country configurations described above (1960-1990; 2007).

\subsubsection{Border analysis}

Our second analysis examines first-order differences in nonmarital fertility, which are defined as the absolute difference in the nonmarital fertility ratio between a region $\mathrm{i}$ and a neighbouring region $\mathrm{j}$. We contrast differences observed between regions divided by state borders with those observed between regions divided by regional borders. Thus, in contrast to the state vs. region analysis, which provides a general account of variation between and within countries regardless of whether they are contiguous, the border analysis takes spatial proximity into account. If state-level structures and processes are relevant for spatial nonmarital fertility patterns, we would expect changes in these patterns to result in the emergence of spatial divides of nonmarital fertility between regions divided by state borders rather than between regions divided by regional borders. To show whether the relevance of state versus regional borders changes over time, we contrast the density curves exhibiting the changes between two cross-sections in the firstorder differences across state borders with those across regional borders. According to

\footnotetext{
${ }^{10}$ Results for the marital fertility ratio are not presented in this paper.
} 
Watkins' expectation, state borders should become less relevant as nonmarital fertility divides after 1990. In addition, the border analysis also allows us to pinpoint the specific borders on maps that are important for the emergence, persistence and disappearance of strong spatial divides in nonmarital fertility. This analysis will provide us with information on which areas of Europe are especially interesting for studying the relationship between political structures and spatial patterns of nonmarital fertility.

We obtain the information on first-order differences through a GIS-procedure that calculates a weight matrix for the GIS-polygon-shapefile with the regions of timeconstant area. This matrix provides information on which regions border each other. In this procedure, we use a first-order queen's definition of contiguity that treats regions as neighbours if their borders meet in at least one common point (Anselin and Rey 1991). We do not consider regions divided by sea to be neighbours. ${ }^{11}$ Deleting all double entries, we obtain from our dataset of 497 regions a border dataset with 1,185 borders. For both the density graphs in Figure 2 and the maps in Figure 3 we divide the borders into two groups: 1) state borders between two neighbouring regions belonging to two different countries; 2) regional borders between two neighbouring regions belonging to the same country. For the country configuration existing between 1960 and 1990 this results in 206 state and 979 regional borders, while for the country configuration of 2007 we obtain 208 state and 977 regional borders.

\footnotetext{
${ }^{11}$ This might create a bias, since regions divided by sea could be closely connected with high levels of communication and movement; for example, Kent, England and Pas-de-Calais, France. However, due to lack of data, we are unable to use any other measures to create alternative specifications.
} 
For both the state and regional borders we calculate the first-order differences through the following formula:

$$
b_{i j}=\left|y_{i}-y_{j}\right|
$$

where $\mathrm{b}$ denotes the absolute first-order difference for each pair of region $\mathrm{i}$ and neighbour region $\mathrm{j}$. These values are used in the border maps in Figure 3. The information for the density graphs (Fig. 2) showing changes in the periods 1960-1975, 1975-1990 and 19902007 is derived by the following formula:

6)

$$
\Delta b_{i j}=\left|y_{i t}-y_{j t}\right|-\left|y_{i t-1}-y_{j t-1}\right|
$$

where $\mathrm{t}$ and $\mathrm{t}-1$ relate to the four cross-sections for which data is available.

A comparison of the state and regional density curves shows which border types are more relevant for shaping spatial pattern of nonmarital fertility. The modifiable areal unit problem is also an issue for this analysis. Results may vary based on different levels of administration. However, we are mainly interested in how these borders change over time, keeping the regional division of the dataset constant. For example strong geographic divides along the state borders of two countries that had not existed in prior periods are unlikely to be driven by the modifiable areal unit problem, but rather by spatial differences in the contextual conditions of nonmarital childbearing. Nevertheless, the results of this part of the analysis have to be interpreted with caution. 


\section{Non Marital Fertility, National Territories and Borders 1960-2007}

Before presenting the results of the statistical analyses, we first turn to the descriptive maps displaying the nonmarital fertility ratio for the four cross-sections (see Fig. 1a-d) ${ }^{12}$. The colour-scheme is based on a time-constant equal-distance categorisation. Figure 1a shows that in 1960, the Golden Age of Marriage was still predominant in most parts of Europe. Almost all countries and regions reported low nonmarital fertility ratios. Notable exceptions were southern Portugal, Iceland, parts of northern Sweden and southern Austria, where nonmarital fertility had already been high in the $19^{\text {th }}$ century, and had been less affected by the general decline of nonmarital fertility in Europe in the first half of the $20^{\text {th }}$ century (see Shorter et al. 1971). Cultural (e.g. Livi-Bacci 1971 on Portugal) and/or policy factors (see e.g. Khera 1981 on Austria) may have played a role in the emergence and persistence of these concentrated areas of nonmarital fertility.

[Figure 1 about here]

In 1975, most of Europe still had low levels of nonmarital fertility (Fig. 1b). Only parts of Sweden witnessed a dramatic increase linked to a resurgence of cohabitation as a social institution (Trost 1978). Elevated levels also emerged in the northern part of Norway and eastern Denmark. From 1975 to 1990 a number of countries in Western and Central Europe experienced a strong increase in nonmarital fertility (Fig. 1c), including Great Britain, France, the German Democratic Republic and Denmark. Policies that pro-

\footnotetext{
${ }^{12}$ For the USSR only data at the level of the Soviet Republics is provided for 1960, 1975 and 1990. For Romania, no regional data is available for 1960, 1975 and 1990.
} 
vided support to single mothers may have promoted the increase in nonmarital childbearing in France (Knijn et al. 2007) and the German Democratic Republic (Salles 2006). Other Western European states, however, such as West Germany, Belgium, the Netherlands, Switzerland, Spain and Italy remained at low levels. In these countries, conservative cultural attitudes coupled with pro-marriage policies and tax incentives discouraged childbearing outside of marriage (e.g. Switzerland: Rossier and Le Goff 2005; Le Goff and Ryser 2010; Belgium: Goldhaber 2007). The checkerboard pattern of countries with high and low nonmarital fertility and clear spatial divides along national borders suggests that national level structures played a role (see also Fig. 3). In a number of countries, however, the increase was restricted to particular regions, for example southern Austria, Slovenia in Yugoslavia, and Estonia and Latvia in the USSR. These examples indicate that factors operating at the regional level were important. Nevertheless, policies may have played a role, for example in Slovenia, the strong increases in nonmarital fertility occurred shortly after it had introduced the most liberal family legislation of all Yugoslavian Republics (see Šarčević 1981).

The map of 2007 (Fig. 1d) continues to show the checkerboard pattern, even though most countries in Western Europe have witnessed substantial increases in nonmarital fertility since 1990. A notable exception in Western Europe is Switzerland, where many regions still report levels below $20 \%$, most likely due to the restricted rights of unmarried fathers that encourage marriage before birth (Rossier and Le Goff 2005; Le Goff and Ryser 2010). Eastern and Southeastern Europe also show a greater pattern of diversity compared to 1990, especially in Southeastern Europe, where the divisions between countries have become more distinct. Slovenia and Hungary, for example, have experi- 
enced strong increases in nonmarital fertility, while neighbouring Croatia has remained at rather low levels. Even stronger are the differences between Bulgaria, which reported the highest rise in nonmarital fertility between 1990 and 2007, and its neighbours - the Former Yugoslavian Republic (FYR) of Macedonia and Greece - which experienced only minor increases. Dating back to the late $19^{\text {th }}$ century, Bulgaria has had a long tradition of implementing policies to overcome traditional family customs and/or influence family formation behaviour (Todorova 2000; Brunnbauer and Taylor 2004). Such a tradition seems to be largely absent in the FYR of Macedonia (Spirovik-Trpenovska 1997) or Greece (Barnes 1998).

Neighbouring Kosovo, Albania and FYR of Macedonia also show distinct patterns, even though a substantial proportion of their populations are Albanian. Of these three political entities only Kosovo has experienced a large increase, most likely due to couples not officially registering their marriages in preference for common law marriage (Rasevic and Petrovic 2001: 3) ${ }^{13}$. Central-Eastern Europe, on the other hand, appears to be divided less by current state borders and more by regional borders, perhaps reflecting previous political regimes. For example, an area with low nonmarital fertility stretches across central and southeastern Poland, western Belarus and western Ukraine, which cor-

\footnotetext{
${ }^{13}$ The Statistical Office of Kosovo uses three categories to distinguish births by marital status: marital births (59.6\% in 2008) and two categories of nonmarital births: extramarital (40.4\%) and illegitimate (0.1\%) (Statistical Office of Kosovo 2009: 15). Extra-marital refers in contrast to illegitimate births to births outside marriage, where paternity has been accepted by a man. If only the illegitimate births would be considered nonmarital, Kosovo would have levels comparable to Albania.
} 
responds to the state territory of Interwar Poland. Increases in nonmarital births seem to be particularly high in regions that witnessed large resettlements after WW II, including northern Bohemia in the Czech Republic and former German territories in Poland. The major interruption these resettlements caused on kinship and community structures might have led the population in these regions to become more receptive to less traditional family patterns (see also Szukalski 2001 on Poland).

Taken together, the four maps show an increase in shades of colour, suggesting that variation across Europe has increased substantially since 1960, when most countries had fewer than $15 \%$ of births outside of marriage. The maps suggest that overall, nonmarital fertility has been diverging across Europe, with some macro-regions experiencing higher levels of fertility and others maintaining relatively low levels. Two different measures of variation confirm these visual impressions: Table 1 presents the standard deviation and inter-quartile range of the non-marital fertility ratio for all 497 regions for each cross-section. Both measures indicate that the variation in nonmarital fertility has been increasing since 1960, with especially steep increases occurring in the period between 1975 and 1990. The slope of the increase was not as steep between 1990 and 2007, but nonetheless nonmarital fertility has continued to diverge.

This divergence in nonmarital fertility across Europe indicates that new behaviours have been emerging at different rates in different places. At first glance, these results may suggest that Watkins' expectation cannot be confirmed: the increase in variation points to national differences persisting as shadings of tone and colour. Despite European integration and the strengthening of supranational institutions and decision making within the 
European Union, nonmarital fertility continues to vary substantially across Europe and does not seem to be converging. Nonetheless, Watkins' primary interest was on the relative impact of states versus subnational regions, and the maps clearly show that both play a role. From the maps, however, we can not tell whether states or regions are more important for leading to the divergence in nonmarital fertility across Europe. Did nonmarital fertility increase in states as a whole, or did they increase region by region? To answer this question, we turn to statistical analysis that will provide greater insights into whether states or regions are more relevant for shaping patterns of nonmarital fertility.

[Table 1 about here]

\subsection{State vs. region analysis}

We now turn to the statistical analyses to test Watkins' expectation that the importance of nation states in shaping the demographic map of Europe faded after 1990. We first present results from the Theil-index analyses on the time-constant regional datasets. Table 2 shows the $R_{B}$-values for the periods $1960,1975,1990$ and 2007 as well as the different country specifications: 1) the 29 countries exiting between 1960 and 1990; and 2) the 37 countries as they were in 2007 . As discussed above, the $\mathrm{R}_{\mathrm{B}}$-measure displays the extent to which the overall variation in nonmarital fertility among the 497 regions can be attributed to differences in the mean regional values obtained for each country. In order to be in line with Watkins' prediction, the $\mathrm{R}_{\mathrm{B}}$-index should decrease after 1990.

The $\mathrm{R}_{\mathrm{B}}$ indicators on Table 2 show that overall, between-country differences account for more of the regional variation in nonmarital fertility than within-country 
differences, corresponding to Watkins' findings for the early $20^{\text {th }}$ century. However, this trend is not constant over time, and some differences arise depending on which of the two country specifications is considered. In 1960, 2/3 of the overall variation can be attributed to between-country differences for both country specifications. However, the 1960 values are the lowest values observed in all cross-sections. In the period 1960 to 1975 , the $\mathrm{R}_{\mathrm{B}}$ Measure for both country specifications dramatically increased, implying that the country dimension became more important to the overall variation in this early phase of the transition towards higher nonmarital fertility. The $\mathrm{R}_{\mathrm{B}}$ value continued to rise in the period 1975 to 1990 , but to a much lower degree. 1990 has the highest $R_{B}$ value with almost $90 \%$ of the overall regional variation attributable to differences between countries $(83 \%$ for the 2007 county specification).

[Table 2 about here]

Since 1990, states have become less important for understanding regional variation across Europe. For both country specifications, the $\mathrm{R}_{\mathrm{B}}$-values of 2007 are lower compared to 1990 . Interestingly, the calculations for the country configuration between 1960 and 1990 result in higher between-country variation for 2007 than those based on the country configuration of 2007. This finding runs counter to our expectation that state border changes would have created a closer match between family behaviour and national states. However, the result is primarily due to the influence of the East-West divide inside Germany, as the 1990 reunification resulted in the merging of two populations with very different family formation strategies (see Klüsener et al. 2012). If we repeat the analysis 
and treat eastern and western Germany as separate countries, the resulting $R_{B}$ is higher compared to that of the country configuration existing between 1960 and 1990.

Overall, the $\mathrm{R}_{\mathrm{B}}$ development seems to confirm Watkins' prediction that after 1990 the state level would lose importance in shaping the demographic map of Europe. However, the variation explained by between-country differences is still substantial. In the following section we will investigate whether this recent increase in the importance of subnational variation is experienced in all parts of Europe, or results from a small number of countries becoming particularly heterogeneous with regard to internal regional nonmarital fertility variation. To examine this, we return to the Theil-within measure (see equations 2 and 3), which is derived by summing the within-country variation contributed by each country. We can decompose this measure to obtain values on the within-country variation of each country with more than one region. Similar to the $R_{B}$ measure, we again standardize the values for each cross-section by dividing them by the overall variation observed in that year. The results are displayed in Table 3. The first line gives the overall sum of the within-country variation of all observed countries, which corresponds to 100$R_{B}$. The countries are ordered in the level of the contribution of their internal regional variation to the overall variation in 2007 , with the most heterogeneous countries at the top $^{14}$. For this table we only consider the country division of $2007^{15}$.

\footnotetext{
${ }^{14}$ It is important to note that the contribution of each country to the variation also depends on the numbers of regions this country is divided in. However, as we already use a standardised measure, we did not want to add another layer of standardisation by e.g. dividing the values by the number of regions.
} 
[Table 3 about here]

The results show Germany's dominant role in contributing to the within-country variation. In $20079 \%$ of the overall variation in our dataset of 497 regions can be attributed to differences within Germany. In the last column of Table 3 we display how the contribution of the within country variation to the overall variation changed for each country between 1990 and 2007. In total, the share of the within-country variation to the total variation was 5.8 percentage points higher in 2007 compared to 1990.5 percentage points of this increase can be attributed to Germany, Poland and Italy. Nevertheless, despite these three countries' high contribution to the change of the $R_{B}$ measure after 1990 , the decline in the relevance of the between-country differences is not entirely driven by them, as almost all countries experienced a reversal in the contribution of their withincountry variation to the overall variation (see Table 3 ). This suggests that the return to the higher relevance of the regional variation relative to the overall variation is a panEuropean trend.

\subsection{Border analysis}

The Theil-Analysis showed that the country dimension explains a significant proportion of the overall regional variation in nonmarital fertility in Europe, especially in 1975 and 1990. However, a shortcoming of the Theil-Analysis is that it treats space hierarchically

\footnotetext{
${ }^{15}$ The values for the country configuration 1960-1990 are similar for all countries that did not experience a change in their set-up.
} 
without taking spatial proximity into account. In other words, the actual placement of regions and countries on the map is irrelevant to the Theil measure. Thus, it cannot tell us whether the countries with high/low values are all clustering in one part of Europe (e.g. North vs. South), which might be linked to large-scale differences in cultural norms, economic development and/or policies, or whether countries with high and low values are scattered across the continent, with many state borders being strong geographic divides in nonmarital fertility. If national structures and processes play a role in shaping the spatial pattern of the increase in nonmarital fertility, we would expect the emergence and strengthening of geographic divides running along state borders, while subnational regional borders should be affected to a much lower degree.

In order to investigate this, we constructed density curves, for which we divided the first-order differences across borders of neighbouring regions into two categories: state borders and regional borders. As explained in the methodological section, we calculate the observed changes in the cross-border differences in the three time periods 1960 1975, 1975-1990 and 1990-2007 to see how these two kinds of borders gained or lost relevance as spatial nonmarital fertility divides. The density curves are presented in Figure 2. The section of the density curves to the left of 0 represents all borders which experienced a decrease in nonmarital fertility differences, while the section to the right of 0 shows those which registered an increase. As above, we face the problem that in the period 1990-2007 some national borders turned into regional borders, and vice-versa. Therefore, we display two graphs for this period. The one in the lower left corner is based on the country configuration existing in 1990, while the one in the lower right corner is based on the one of 2007 . 
[Figure 2 about here]

In all four graphs of Figure 2, the density curves of the state borders are lower and wider than the steeper density curves of the regional borders. This indicates that over the last 50 years state borders more frequently experienced substantial increases (or decreases) in cross-border differences in nonmarital fertility than regional borders. The density curve of the regional border is centred around 0 showing that regional borders were more likely to experience no change at all. Particularly in the periods 1975-1990 and 1990-2007 did the cross-border differences in nonmarital fertility increase along a large number of state borders relative to regional borders. Interestingly, state borders not only more often experienced an emergence in nonmarital fertility divides, they were also more likely to register large decreases. This is especially true for the period 1990-2007. Overall, Figure 2 portrays a mixed picture with regard to Watkins' expectation. After 1990 state borders were more likely to experience an increase in first-order cross-border differences, which counters her expectation. On the other hand, the differences between the density curves of the state and regional borders were less distinct in the period 19902007 compared to the period 1975-1990, providing support for her expectation. Another aspect which supports her prediction is that state borders in the period 1990-2007 were more likely to experience a decrease in first-order nonmarital fertility differences. Nevertheless, today state borders continue to be much more relevant to spatial patterns of nonmarital fertility compared to regional borders (see also Figure 3).

Besides this general pattern, the border analysis also allows us to identify specific European borders which emerge or persist as spatial divides of nonmarital fertility. Fig- 
ure 3 presents maps of first-order differences across state and regional borders for the four cross-sections. As in Figure 1, we use an equal-distance categorisation scheme. The larger the size of the circle on a border, the higher the first-order difference in nonmarital fertility across this border in percentage points. State borders are represented by red circles, regional borders by black ones. In 1960 the most prominent borders outlined regions with traditionally elevated levels of nonmarital fertility (e.g. southern Portugal, central Sweden and southern Austria). By 1975 this had changed, with the most prominent borders situated in Scandinavia, particularly between southern Norwegian regions and neighbouring regions in central Sweden.

[Figure 3 about here]

In 1990, only a small number of borders in Scandinavia still displayed strong differences in nonmarital fertility; instead, all of Northern Europe had experienced increases. Now the most prominent divides were located in Western Europe, where new hot spots of nonmarital fertility had emerged between 1975 and 1990. East Germany, for example, exhibited strong cross-border differences in nonmarital fertility across almost all of its national borders. The same is true for France. Very interesting is the emergence of divides across the French-Belgian and the French-Swiss border, since the populations on both sides of these borders speak French. Even though these borders were not linguistic divides, they became divides in demographic behaviour. This suggests that processes at the national level play a role in shaping this pattern.

As discussed above, Swiss policies on unmarried fathers are likely to have contributed to this development (Rossier and Le Goff 2005). In Belgium policies might have 
played a role, as the civil legislation strongly discriminated against children born out of wedlock and their mothers until the late 1980s (see Goldhaber 2007: 15 ff.). An unmarried mother did not automatically get maternity rights, and in order to obtain these rights she either had to undergo an administrative procedure or adopt her own child. These regulations set high incentives for unmarried parents to marry prior to birth. In 1979, the European Court of Human Rights ruled in the Marckx-decision that these legal regulations were not in accordance with Art. 8 (private and family life) and Art. 14 (nondiscrimination) of the European Convention on Human Rights. To comply, the Belgium government amended its civil code in 1987. In France, on the other hand, such discriminating regulations had already long been abolished. These differences may have had an impact on the emergence of a nonmarital fertility divide between France and Belgium in the 1970s and 1980s, and its disappearance in the period after 1990. The role of the European Court of Human Rights can be considered an example of how a supranational institution can influence national policies, thereby reducing state-level differences in legislation related to nonmarital childbearing between countries.

When we contrast the 1990 map with the 2007 map, we see that most of the substantial geographic divides have shifted to Southern and Southeastern Europe. In Northern and Western Europe, the only remaining strong dividing line is between western and eastern Germany. The persistence of this boundary seems to be surprising, since family policies were harmonised in Germany after unification in 1990. But research by Klüsener et al. (2012) has shown that the nonmarital fertility divide between western and eastern Germany dates back at least to the $19^{\text {th }}$ century and is linked to long standing differences in the degree of secularisation and legislation related to nonmarital children and 
their mothers. This, together with the political and economic developments of the $20^{\text {th }}$ century, makes it very unlikely that the German East-West differences will fade anytime soon.

Overall, our analysis suggests that the strongest distinctions along state borders emerged in the early phase of the transition to higher nonmarital fertility within a European macro-region. In 1975, most of the strong divides were found in Scandinavia, where rates had started to increase in some areas but not others. Between 1975 and 1990, the strongest dividing lines had emerged around countries in Western and Central Europe, where some countries such as France, the United Kingdom and East Germany had experienced strong increases, while neighbouring states lagged behind in this process. By 2007, the most prominent dividing lines had shifted to Southeastern Europe, where Bulgaria and Kosovo were experiencing the greatest increases. However, these strong divides along state borders usually only existed for a limited period of time; once nonmarital fertility gained momentum in a particular European macro-region, the most prominent dividing lines shifted to other macro-regions. Nevertheless, some state borders, such as the border between France and Switzerland or between France and Italy seem to be quite persistent over time.

\section{Discussion and Conclusion}

In this paper we explored how spatial patterns of nonmarital fertility changed across Europe over the last 50 years. We found that the variation in nonmarital fertility 
dramatically increased over time, indicating that some areas of Europe experienced great increases in nonmarital childbearing, while others maintained relatively low levels. Following the work of Susan Watkins $(1990,1991)$, we also examined the role of states, regions, and their borders in shaping spatial patterns of nonmarital fertility. Overall, we found that nation states and their borders continue to be very important for describing nonmarital fertility. Contrary to Watkins' prediction, national borders have remained deeply etched on the map of Europe. However, we also found that the role of state borders decreased relative to regional borders in the latest period between 1990 and 2007. This finding suggests that regional factors such as cultural norms, economic conditions, or local family policies may have gained in importance.

Our analyses also pinpointed a number of strong geographic divides of nonmarital fertility along national borders. Most of these divides emerged as nonmarital fertility increased in a given macro-region and faded as nonmarital fertility became more normative in that macro-region. The most significant divides then emerged in other macro-regions which were only just starting to experience increases in nonmarital fertility. Such results have to some degree also been found in spatial research on fertility decline during the first demographic transition (Bocquet-Appel and Jakobi 1996: 120 ff.). Nonetheless, our results also show that some nonmarital fertility divides have been quite persistent over time. For example, the border between Switzerland and France has continued to separate two countries with high and low nonmarital fertility despite a similar language and substantial economic ties. The differences between the two countries may be due to different norms, civil legislation, or policies related to marriage and nonmarital childbearing (Le Goff and Ryser 2010). Thus, our analysis shows that even though new patterns of behav- 
iour may diffuse across national borders rendering them less important, the national context can still be very influential for shaping nonmarital fertility.

It is important to remember that while this paper examines macro-level processes - the shaping of patterns of nonmarital fertility at the state and regional level - the decisions that produce these aggregates occur at the micro-level. Fundamentally, the increase in nonmarital fertility across Europe is the result of the increase in childbearing within cohabitation, as couples postpone or forego marriage (Perelli-Harris et al. forthcoming). Proponents of the Second Demographic Transition posit that increases in cohabitation and childbearing within cohabitation may be due to shifts in values towards individualisation, autonomy, and secularisation, values that may have led to a rejection of the institution of marriage (Lesthaeghe and Neels 2002; Lesthaeghe 2010). On the other hand, rising economic insecurity may also have led couples to remain in cohabitation rather than marry, as suggested by the negative educational gradient of childbearing outside of marriage (Perelli-Harris et al. 2010). Our paper shows that regardless of the underlying changes occurring at the individual-level, macro-level contexts remain important influences on behaviour. Changes in behaviour diffuse over space, but are often delineated by borders, whether at the regional or state level.

Our results also suggest that state or regional policies may play a role in encouraging or discouraging certain behaviours. Policies and legislation regarding marriage and cohabitation differ greatly across Europe, with some countries treating cohabitation and marriage nearly the same and other countries continuing to privilege marriage (PerelliHarris and Sánchez Gassen 2010). These policies may in turn influence behaviour, for 
example discouraging childbearing outside of marriage, as in the case of Switzerland. Nonetheless, it is difficult to know whether the policies influenced the behaviour or the changing behaviour prompted changes in legislation. The relationship is reciprocal, and just as there are feedback loops between demographic behaviours and social institutions (for example, the increase in divorce leads to changes in the institution of marriage which in turn leads to further increases in divorce) (Bumpass 1990), there are also feedback loops between union formation behaviours and the state policies that regulate those behaviours.

On the other hand, external factors can also interfere with the interplay between policies and behaviour, and as a consequence change either of them. Supranational institutions most likely contributed to some of the changes that we see on the maps by passing initiatives that reduced the stigma of out-of-wedlock childbearing in national legislation. The example of Belgium showed that the stark nonmarital divide between Belgium and France disappeared in the late 1980s, after the European Court of Human Rights pressured the Belgian government to change some of its discriminatory laws. Although our macro-level analyses cannot provide concrete evidence that supranational institutions caused these changes, it is likely that European integration facilitated the diffusion of nonmarital fertility by fostering joint economic activities and immigration, consolidating media and communication, and harmonizing certain types of family law.

Finally, it is unclear whether nonmarital fertility will continue to increase across Europe and eventually converge, or whether the borders that we see will remain deeply etched on the map of Europe. On the one hand, continued European integration may 
promote the diffusion of cohabitation, and nonmarital fertility may become much more widespread. This may lead national borders to fade, as Watkins predicted. On the other hand, differences in values and norms related to family formation and childbearing may persist across regions and states in Europe, and nonmarital fertility behaviour may continue to vary across borders. It will be the task of future research to show whether the political and economic integration of Europe will eventually trigger an ideational and demographic homogenization, or whether Europe's demographic behaviour will remain united in diversity.

\section{References}

Agnew, J. (2008). Borders on the mind: re-framing border thinking. Ethics and Global Politics, 1(4), 175-191.

Anselin, L., \& Rey, S. (1991). Properties of tests for spatial dependence in linear regression models. Geographical Analysis, 23(2), 112-131.

Barnes, H. (1998). Cohabiting couples without children. In L.A. Vaskovics, H.A. Schattovits (Eds.), Lebens- und Familenformen - Tatsachen und Normen (pp. 83-88). 2. Europäischer Fachkongreß Familienforschung 12.-14. Juni 1997.

Bocquet-Appel, J.P., \& Jakobi, L. (1996). Barriers to the spatial diffusion for the demographic transition in Western Europe. In J.P. Bocquet-Appel, D. Corgeau, \& D. Pumain (Eds.), Spatial Analysis of Biodemographic Data (pp. 107-123). Montrouge: John Libbey Eurotext. 
Brunnbauer, U., \& Taylor, K. (2004). Creating a 'socialist way of life': family and reproduction policies in Bulgaria 1944-1989. Continuity and Change, 19(2), 283-312.

Bumpass, L. (1990). What's happening to the family? Interactions between demographic and institutional change. In: Demography, 27, 483-498.

Castiglioni, M., \& Dalla Zuanna, G. (2009). Marital and reproductive behavior in Italy after 1995: Bridging the gap with Western Europe? European Journal of Population, 25, 1-26.

Coale, A.J., \& Watkins, S.C. (eds.) (1986). The Decline of Fertility in Europe. Princeton: Princeton University Press.

Coester, M. (1993). Entwicklungslinien im europäischen Nichtehelichenrecht. Zeitschrift für Europäisches Privatrecht, 1, 536-553.

Council of Europe (2005). Recent demographic developments in Europe 2004. Strasbourg: Council of Europe Publishing.

Decroly, J.M., \& Grasland, C. (1993). Boundaries, political systems and fertility in Europe. Population: An English Selection, 5, 101 - 119.

Decroly, J.M., \& Vanlaer, J. (1991). Atlas de la Population Européenne. Brussels.

DiMaggio, P., Hargittai, E., Russell Neuman, W., \& Robinson, J.P. (2001). Social implications of the Internet. Annual Review of Sociology, 27, 307-336.

Esping-Andersen, G. (1999). Social Foundations of Post-Industrial Economies. Oxford: Oxford University Press

Goldhaber, M.D. (2007). A People's History of the European Court of Human Rights. Piscataway: Rutgers University Press. 
González Beilfuss, C. (2005). Spanien und Portugal. In J.M. Scherpe, \& N. Yassari (Eds.): Die Rechtsstellung nichtehelicher Lebensgemeinschaften, Beiträge zum ausländischen und internationalen Privatrecht (pp. 249-275). Tübingen: Mohr Siebeck

Goodchild, M.F., \& Lam, N. S.-N. (1980). Areal interpolation: A variant of the traditional spatial problem. Geo-Processing, 1, 297-312.

Graham, S. (1998). The end of geography or the explosion of place? Conceptualizing space, place and information technology. Progress in Human Geography, 22,2, 165-185.

Gregory, I. (2002). The accuracy of areal interpolation techniques: Standardising $19^{\text {th }}$ and $20^{\text {th }}$ century census data to allow long-term comparisons. Computers Environment and Urban Systems, 26, 293-314.

Gregory, I., Marti-Henneberg, J., \& Tapiador, F.J. (2010). Modelling long-term pan European population change from 1870 to 2000 by using geographical information systems. Journal of the Royal Statistical Society, 173(1), 31-50.

Heady, P., \& Kohli, M. (eds.) (2010). Family kinship and state in contemporary Europe. Frankfurt am Main. Three Volumes: Campus Verlag

Held, D., \& McGrew, A.G. (1993). Globalization and the liberal democratic state. Government \& Opposition, 28(2), 261-285.

Khera, S. (1981). Illegitimacy and mode of land inheritance among Austrian peasants. Ethnology, 20, 307-323.

Kiernan, K. (2004). Unmarried cohabitation and parenthood in Britain and Europe. Law \& Policy, 26, 33-55. 
Klüsener, S., \& Kreyenfeld, M. (2009). Nichteheliche Geburten im regionalen Vergleich. Nationalatlas aktuell 10/2009.

Klüsener, S., Szołtysek, M., Goldstein, J.R. (2012). Towards an integrated understanding of demographic change and its spatio-temporal dimensions: Concepts, data needs, and example case studies. Die Erde [forthcoming].

Kok, J. (2009). Family systems as frameworks for understanding variation in extramarital births, Europe 1900-2000. Romanian Journal of Population Studies, Supplement 2009, 13-38.

Knijn, T., Martin, C., Millar, J. (2007). Activation as a framework for social policies towards lone parents. Social Policy and Administration, 41, 638-652.

Krause, H. (1976). Creation of relationships of kinship. In A. Chloros, M. Rheinstein, \& M.A. Glandon (Eds.), International Encyclopedia of Comparative Law IV (Ch. 6.19.). Tübingen: Mohr Siebeck.

Lefebvre, H. (1991). The Production of Space. Oxford: John Wiley \& Sons.

Le Goff, J.-M., \& Ryser, V.-A. (2010). The meaning of marriage for men during their transition to fatherhood: The Swiss context. Marriage \& Family Review, 46, 107125.

Lesthaeghe, R. (1980). On the social control of human reproduction. Population and Development Review, 6, 527-548.

Lesthaeghe, R. (2010). The unfolding story of the Second Demographic Transition. Population and Development Review, 36(2), 211-251. 
Lesthaeghe R., \& Neels, K. (2002). From the First to the Second Demographic Transition: An interpretation of the spatial continuity of demographic innovation in France, Belgium and Switzerland. European Journal of Population, 18, 325-360.

Lesthaeghe, R., \& Neidert, L. (2006). The Second Demographic Transition in the United States: Exception or textbook example? Population and Development Review, 32, 669-698.

Livi Bacci, M. (1971). A Century of Portuguese Fertility. Princeton: Princeton University Press.

McLaughlin, E., \& Glendinning, C. (1994). Paying for care in Europe: Is there a feminist approach? In L. Hantrais, \& S. Mangen, (Eds.), Family Policy and the Welfare of Women (pp. 52-69). Loughborough: Cross-National Research Group.

Openshaw, S. (1984). The modifiable areal unit problem. Concepts and Techniques in Modern Geography 38. Norwich: Geo Books.

Perelli-Harris, B., Kreyenfeld, M., Sigle-Rushton, W., Keizer, R, Lappegård, T., Jasilioniene, A., Berghammer,C., \& Di Giulio, P. (forthcoming). Changes in union status during the transition to parenthood: An examination of 11 European countries. Population Studies.

Perelli-Harris, B., \& Gerber, T.P. (2011). Nonmarital fertility in Russia: Second demographic transition or pattern of disadvantage. Demography, 48(1), 317-342.

Perelli-Harris, B., \& Sánchez Gassen, N. (2010). The reciprocal relationship between the state and union formation across Western Europe: Policy dimensions and theoretical considerations. Rostock. MPIDR Working Paper 2010-034. 
Perelli-Harris, B., Sigle-Rushton, W., Lappegard, T., Keizer, R., Kreyenfeld, M., \& Berghammer, C. (2010). The educational gradient of childbearing with cohabitation in Europe. Population and Development Review, 36(4), 775-801.

Rasevic, M., \& Petrovic, M. (2001). Is there a basis for implementing a family planning program in Kosovo and Metohija? Volos. Balkan Demographic Papers 2001/ 4.

Reher, D.S. (1998). Family ties in Western Europe: Persisting contrasts. Population and Development Review, 24(2), 203-234.

Rey, S.J. (2004). Spatial analysis of regional income inequality. In M.F. Goodchild, D.G. Janelle (Eds.), Spatially Integrated Social Science. Oxford: Oxford University Press.

Rossier, C., \& Le Goff, J.-M. (2005). Le calendrier des maternities : Retard et diversification de la réalisation du projet familial. In J.-M. Le Goff, C. Sauvain-Dugerdil, C. Rossier, J. Coenen-Huther, (Eds.), Maternitè et parcours de vie. Bern: Peter Lang.

Salles, A. (2006). The effects of family policy in the former GDR on nuptiality and births outside marriage. Population (English edition), 61, 131-142.

Šarčević, P. (1981). Cohabitation without marriage : The Yugoslavian experience. The American Journal of Comparative Law, 29(2), 315-338.

Shorter, E., Knodel, J., \& Van de Walle, E. (1971). The decline of non-marital fertility in Europe, 1880 - 1940. Population Studies, 25, 375-393.

Spirovik-Trpenovska, L. (1997). Macedonia : Development of family law in Macedonia. In International Society of Family Law (Ed.), The International Survey of Family Law 1997. The Hague: Martinus Nijhoff. 
Sprangers, A., \& Garssen, J. (2003). Non-marital fertility in the European Economic Area. The Hague. http://www.cbs.nl/NR/rdonlyres/441AC4F4-0ED5-4E32B12D-A100BC83552E/0/nonmarital.pdf

Statistical Office of Kosovo (2009). Series 4: Statistics of Population : Statistics of Births in Kosovo 2008. Pristina.

Szukalski, P. (2001). Płodność i urodzenia pozamatżeoskie w Polsce. Łódź.

Theil, H. (1965). The information approach to demand analysis. Econometrica, 33(1), 6787.

Thornton, A., \& Philipov, D. (2009). Sweeping changes in marriage, cohabitation and childbearing in Central and Eastern Europe: New insights from the developmental idealism framework. European Journal of Population, 25, 123-125.

Todorova, V. (2000). Family law in Bulgaria : Legal norms and social norms. International Journal of Law, Policy and the Family, 14, 148-181.

Trost, J. (1978). A renewed social Institution : Non-marital cohabitation. Acta Sociologica, 21, 303-315.

Watkins, S.C. (1990). From local to national communities: The transformation of demographic regimes in Western Europe, 1870-1960. Population and Development Review, 16(2), 241-272.

Watkins, S.C. (1991). From Provinces into Nations: Demographic Integration in Western Europe 1870-1960. Princeton: Princeton University Press. 
Fig. 1 Nonmarital Birth Ratio Development across European Regions, 1960-2007

a)
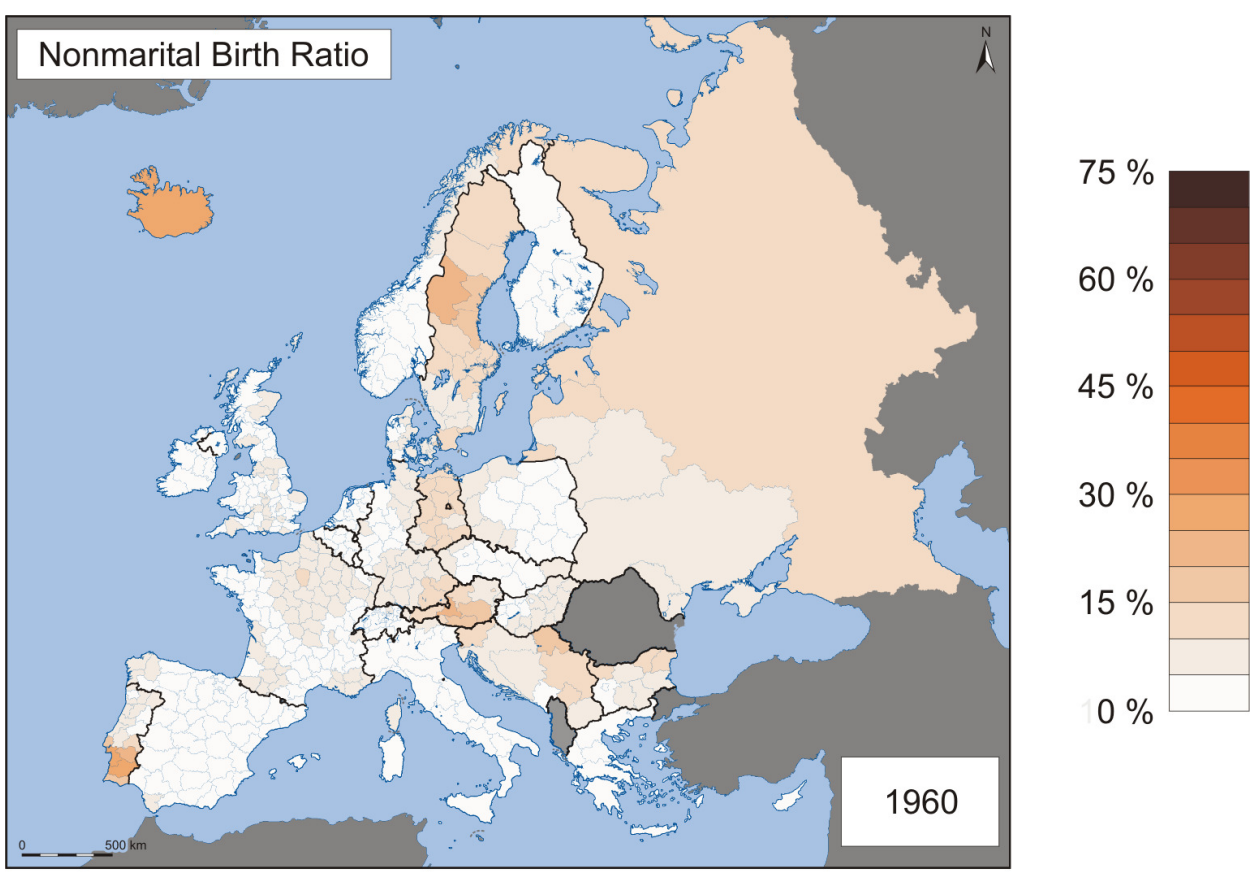

Source: Decroly \& Vanlaer (1991); Council of Europe (2005); own calculations Base Map: MPIDR \& CGG; partly based on () EuroGeographics for the administrative boundaries

b)
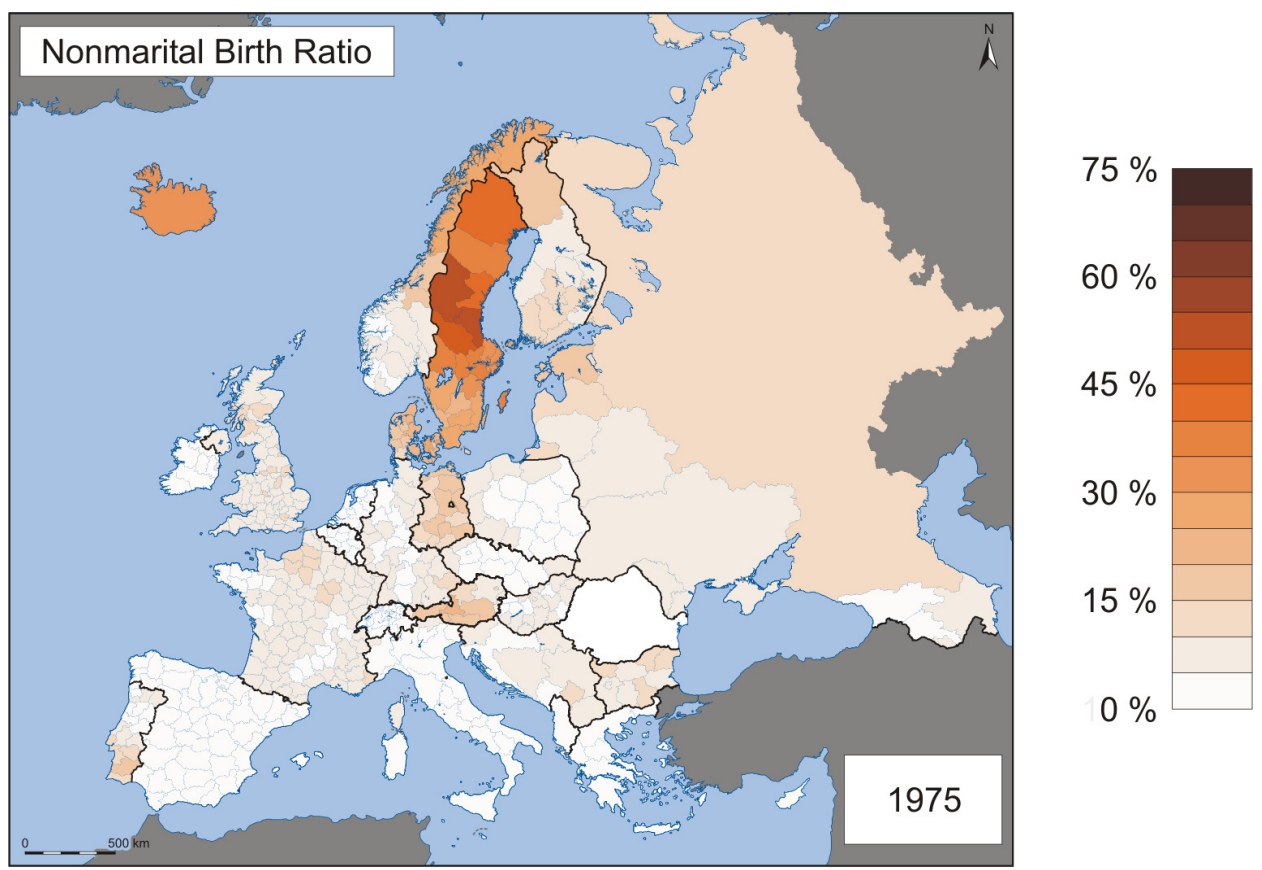
Base Map: MPIDR \& CGG; partly based on (@) EuroGeographics for the administrative boundaries 
c)
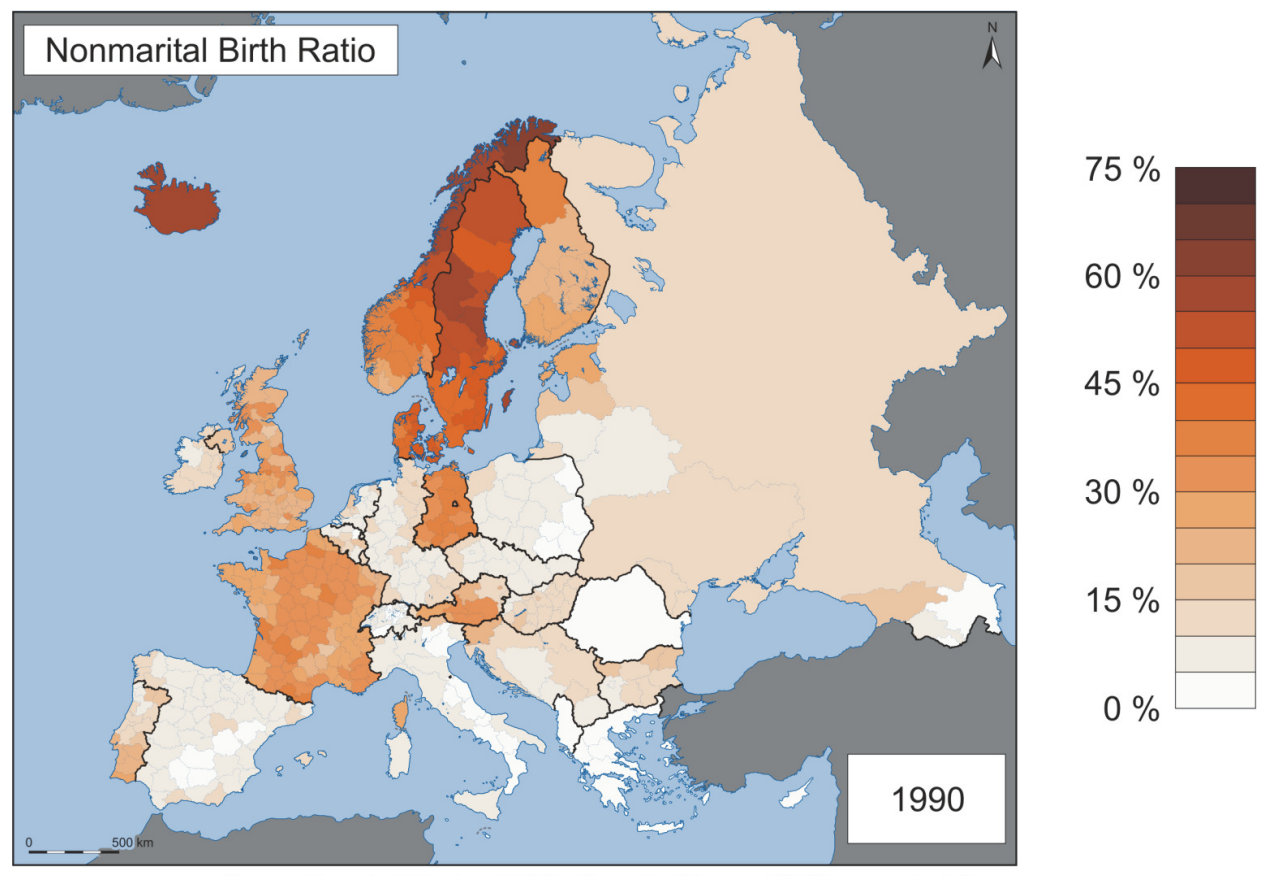

Source: Decroly \& Vanlaer (1991): Council of Europe (2005); own calculations Base Map: MPIDR \& CGG; partly based on () EuroGeographics for the administrative boundaries

d)
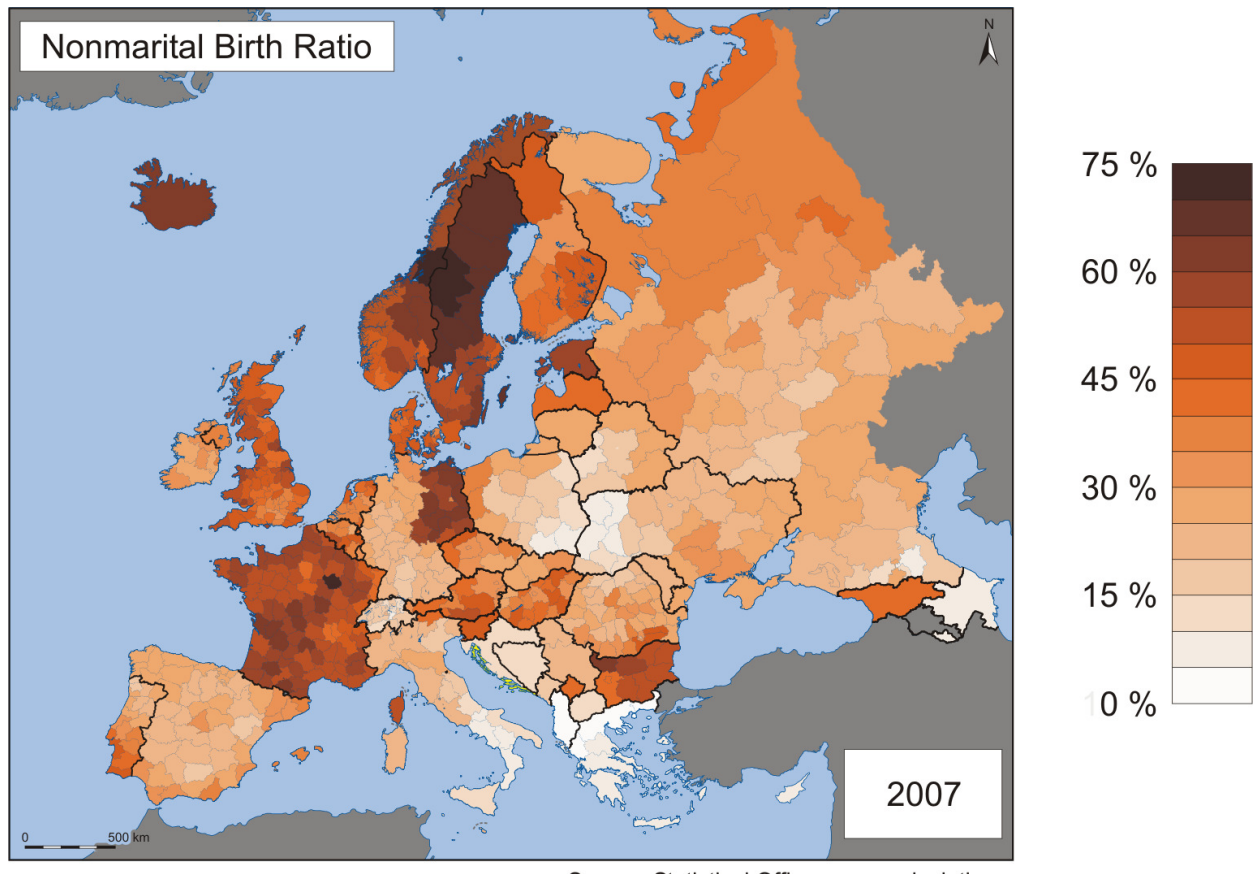

Base Map: MPIDR \& CGG; partly based on () EuroGeographics for the administrative boundaries 
Tab. 1: Overall Regional Variation in the Nonmarital Birth Ratio, 1960-2007

\begin{tabular}{lccccc}
\hline Measure & Regions (N) & $\mathbf{1 9 6 0}$ & $\mathbf{1 9 7 5}$ & $\mathbf{1 9 9 0}$ & $\mathbf{2 0 0 7}$ \\
\hline Standard deviation & 497 & 3.98 & 7.76 & 13.73 & 15.85 \\
\hline Inter-quartile range & 497 & 3.78 & 5.59 & 22.93 & 25.74 \\
\hline
\end{tabular}

Sources: Statistical Offices; Decroly and Vanlaer (1991); Council of Europe (2005); own calculations

Tab. 2: $\mathbf{R}_{\mathrm{B}}$ - \%-Share of Between-country Nonmarital Birth Ratio Variation in Total Variation, $1960-2007$

\begin{tabular}{lccccc}
\hline Countries & Regions (N) & $\mathbf{1 9 6 0}$ & $\mathbf{1 9 7 5}$ & $\mathbf{1 9 9 0}$ & $\mathbf{2 0 0 7}$ \\
\hline $\begin{array}{l}\text { Country set-up 1960-1990 } \\
\text { (before collapse of social- } \\
\text { ism) (29 countries) }\end{array}$ & 497 & 67.1 & 85.2 & 89.0 & 84.2 \\
\hline $\begin{array}{l}\text { Country set-up 2007 } \\
\text { (after collapse of socialism) } \\
\text { (37 countries) }\end{array}$ & 497 & 66.8 & 82.2 & 83.3 & 77.5 \\
\hline
\end{tabular}

Sources: Statistical Offices; Decroly and Vanlaer (1991); Council of Europe (2005); own calculations 
Tab. 3: Share of Total Nonmarital Birth Ratio Variation attributable to Within-country Variation, 1960-2007 (Country specification for 2007)

\begin{tabular}{lcccccc}
\hline Country & Regions & $\mathbf{1 9 6 0}$ & $\mathbf{1 9 7 5}$ & $\mathbf{1 9 9 0}$ & $\mathbf{2 0 0 7}$ & $\begin{array}{c}\text { Change } \\
\mathbf{1 9 9 0} \\
\mathbf{2 0 0 7}\end{array}$ \\
\hline All countries & & & & & & \\
\hline Germany & 497 & 33.2 & 17.8 & 16.7 & 22.5 & 5.8 \\
\hline Italy & 46 & 5.0 & 4.5 & 7.1 & 9.3 & 2.2 \\
\hline United Kingdom & 21 & 0.7 & 0.6 & 0.7 & 2.1 & 1.4 \\
\hline Poland & 67 & 1.1 & 1.1 & 1.6 & 1.9 & 0.3 \\
\hline Portugal & 16 & 1.1 & 0.2 & 0.2 & 1.6 & 1.4 \\
\hline France & 18 & 7.9 & 1.3 & 1.0 & 1.4 & 0.4 \\
\hline Spain & 89 & 3.7 & 1.9 & 1.0 & 1.2 & 0.2 \\
\hline Norway & 48 & 3.9 & 0.5 & 0.7 & 1.0 & 0.3 \\
\hline Sweden & 19 & 2.5 & 3.1 & 1.1 & 0.7 & -0.4 \\
\hline Switzerland & 21 & 2.2 & 1.7 & 0.2 & 0.5 & 0.3 \\
\hline Hungary & 24 & 0.8 & 0.1 & 0.3 & 0.5 & 0.2 \\
\hline Austria & 20 & 0.4 & 0.2 & 0.2 & 0.4 & 0.2 \\
\hline Belgium & 9 & 0.9 & 0.7 & 0.6 & 0.3 & -0.3 \\
\hline Finland & 9 & 0.4 & 0.1 & 0.4 & 0.3 & -0.1 \\
\hline Czech Republic & 12 & 0.1 & 0.7 & 0.6 & 0.3 & -0.3 \\
\hline Bulgaria & 8 & 0.5 & 0.2 & 0.2 & 0.2 & 0.0 \\
\hline Netherlands & 9 & 0.9 & 0.1 & 0.1 & 0.2 & 0.1 \\
\hline Greece & 11 & 0.2 & 0.1 & 0.3 & 0.2 & -0.1 \\
\hline Denmark & 9 & 0.1 & 0.0 & 0.0 & 0.2 & 0.2 \\
\hline Ireland & 14 & 0.6 & 0.4 & 0.1 & 0.1 & 0.0 \\
\hline Slovakia & 7 & 0.0 & 0.0 & 0.2 & 0.1 & -0.1 \\
\hline Serbia & 3 & 0.1 & 0.0 & 0.0 & 0.0 & 0.0 \\
\hline & 2 & 0.0 & 0.0 & 0.0 & 0.0 & 0.0 \\
\hline
\end{tabular}

Sources: Statistical Offices; Decroly and Vanlaer (1991); Council of Europe (2005); own calculations 
Fig. 2: Density Curves of Changes in First-Order Cross-Border Nonmarital Fertility Ratio Differences between two Cross-Sections (State vs. Regional Borders)
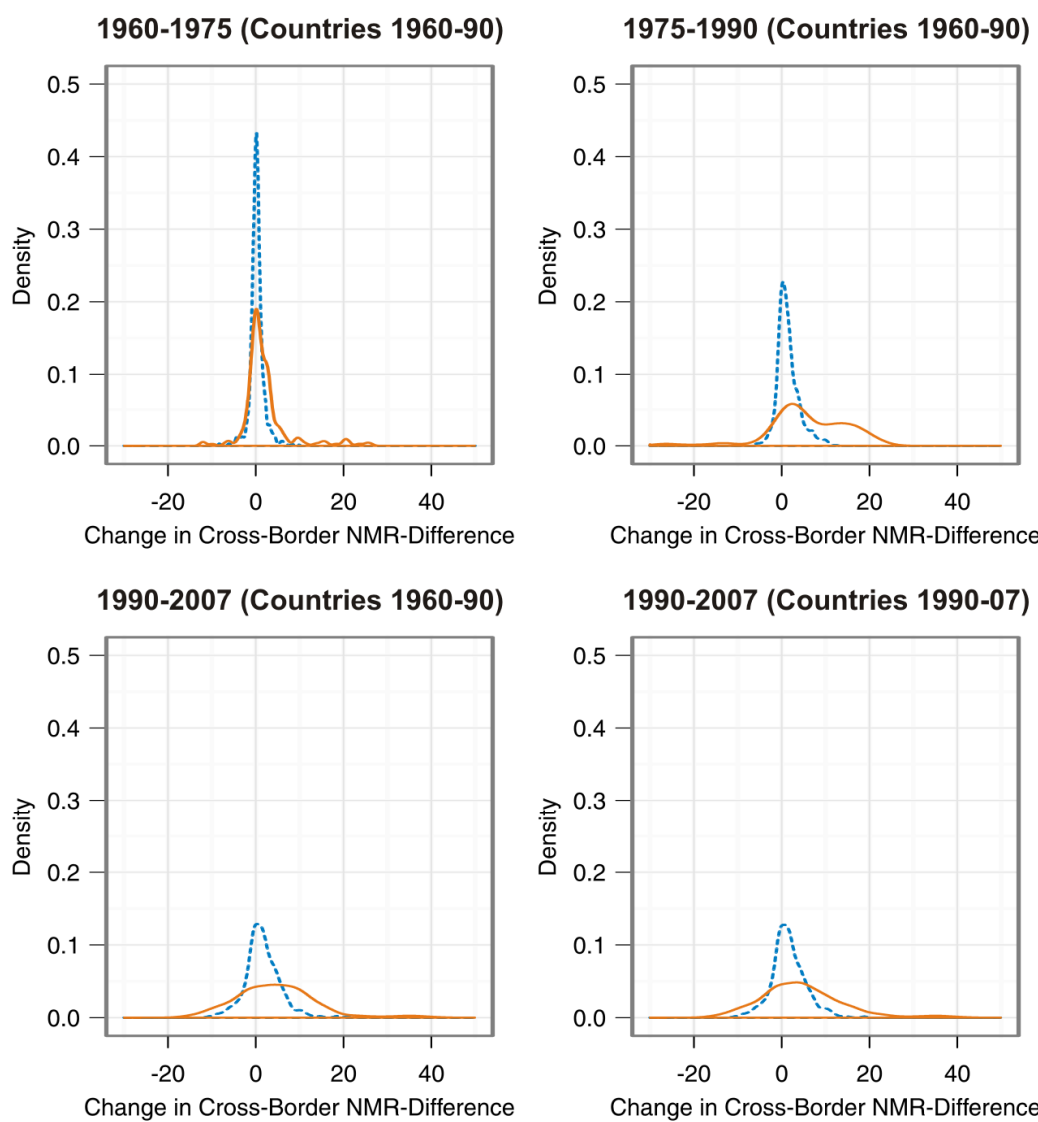

\section{Border Type \\ - State \\ -.. Regional}

Change in Cross-Border NMR-Difference

Change in Cross-Border NMR-Difference

Sources: Statistical Offices; Decroly \& Vanlaer (1991); Council of Europe (2005); own calculations Base Map: MPIDR \& CGG; partly based on @ EuroGeographics for the administrative boundaries 
Fig. 3: First-Order Cross-Border Nonmarital Fertility Ratio Differences, 1960-2007

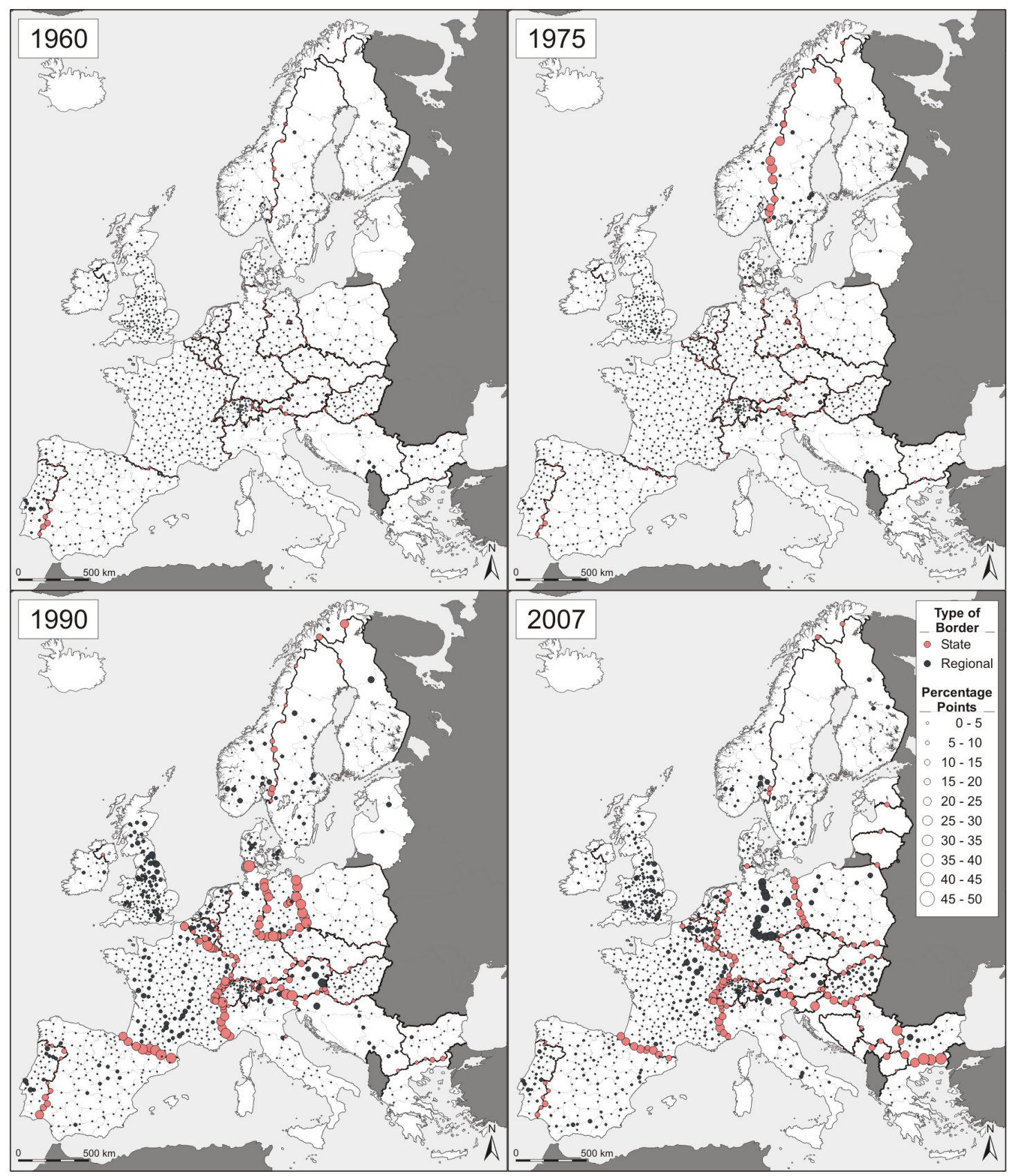

Sources: Statistical Offices; Decroly \& Vanlaer (1991); Council of Europe (2005); own calculations Base Map: MPIDR \& CGG; partly based on (C) EuroGeographics for the administrative boundaries 


\section{Appendix 1. Time-Constant Regions incl. Estimation Procedures}

\begin{tabular}{|c|c|}
\hline Country & NUTS/ LAU-Level and Estimations \\
\hline Austria & NUTS2: nine states (Bundesländer) \\
\hline Belgium & NUTS2: nine provinces (provincie) (set-up 1977 until 1995) \\
\hline & $\begin{array}{l}1960 \text { and 1975: we use the published province data, ignoring small border modifi- } \\
\text { cations of the 1963- and 1977-reforms }\end{array}$ \\
\hline Bulgaria & NUTS2: 9 regions (oblasts) (set-up 1986 until1998) \\
\hline Czech Republic & NUTS2: eight regions (old krajs) \\
\hline Denmark & $\begin{array}{l}\text { NUTS3: } 16 \text { regions (amter) existing until } 2006 \text { (aggregated to } 14 \text { regions). } \\
\text { 2007: estimations based on data for the } 99 \text { LAU-1 municipalities (kommuner). }\end{array}$ \\
\hline Finland & $\begin{array}{l}\text { NUTS3: } 12 \text { provinces (lääni, län) existing between } 1960 \text { and } 1997 \\
\text { 2007: estimations based on data for the current } 20 \text { Finnish NUTS3 regions (maa- } \\
\text { kunat, landskap). }\end{array}$ \\
\hline France & NUTS3: 95 regions (departments) (aggregated to 89 regions) \\
\hline Germany & $\begin{array}{l}\text { West Germany (NUTS2): } 31 \text { regions (Bundesländer/ Regierungsbezirke) (in the } \\
\text { borders existing prior to 1990) } \\
\text { East Germany ( NUTS2-NUTS3): } 15 \text { GDR regions (Bezirke) } \\
\text { 2007: for West and East Berlin estimations are based on 2006-data for the } 12 \text { city } \\
\text { districts (Bezirke). } \\
\text { 2007: for GDR-Bezirke except East Berlin estimations are based on data for } 102 \\
\text { NUTS3 districts (Kreise) } \\
\text { 1975: estimates for West Germany are based on data for } 343 \text { districts ( NUTS3) } \\
\text { 1960: estimates for West Germany are based on data } 565 \text { districts ( NUTS3) }\end{array}$ \\
\hline Greece & NUTS2: 9 traditional regions (geografika diamerismata) existing until 1987 \\
\hline Hungary & NUTS3: 20 counties (megye) \\
\hline Ireland & NUTS3: eight regions existing since 1994 (aggregated to seven regions) \\
\hline Italy & NUTS2: 21 regions (regioni) \\
\hline Netherlands & NUTS2: 12 provinces (provincies) (aggregated to 11 regions) \\
\hline Norway & NUTS3: 19 counties (fylker) \\
\hline Poland & $\begin{array}{l}\text { NUTS2: } 16 \text { regions (wojwods) } \\
\text { 1960: estimations based on } 22 \text { regions (wojwods) existing until } 1974 \text { ( NUTS2) } \\
\text { 1975/ 1990: estimations based on the } 49 \text { regions (wojwods) existing between } 1975 \\
\text { and 1998 ( NUTS3) }\end{array}$ \\
\hline Portugal & NUTS2-NUTS3: 18 districts (distritos) (Acores and Madeira are excluded) \\
\hline Serbia & NUTS2: division into two regions: Central Serbia and Vojvodina (pokraine) \\
\hline Slovakia & NUTS2: three regions (krajs) which existed in 1960 \\
\hline Spain & $\begin{array}{l}\text { NUTS3: } 50 \text { provinces (provincias) (two provinces on Canary Islands as well as } \\
\text { Ceuta and Melilla are excluded) }\end{array}$ \\
\hline Sweden & NUTS3: 21 regions (län) \\
\hline Switzerland & NUTS3: 26 regions (Kantone) (aggregated to 24 regions) \\
\hline $\begin{array}{l}\text { United King- } \\
\text { dom }\end{array}$ & $\begin{array}{l}\text { England Scotland and Wales (NUTS2-NUTS3): } 66 \text { counties existing between } \\
\text { 1974/ } 1975 \text { and } 1992 . \\
\text { 1960: estimates based on data for } 95 \text { regions existing until 1974/ } 1975 \\
\text { 2007: estimates based on data for } 136 \text { counties and unitary authorities ( NUTS3) } \\
\text { Northern Ireland (NUTS1) }\end{array}$ \\
\hline
\end{tabular}

For the following countries no subdivisions are considered: Bosnia-Herzegovina, Cyprus, Croatia, Estonia, FYR of Macedonia, Iceland, Kosovo, Latvia, Liechtenstein, Lithuania, Luxembourg, Malta, Montenegro, San Marino and Slovenia. 
Appendix 2. Countries for which Cross-sectional Data deviates from the Cross-Sectional Year

\begin{tabular}{ll}
\hline Cross-Section & Countries \\
\hline $\mathbf{1 9 6 0}$ & Bulgaria (1961), Cyprus (1961), Czechoslovakia (1965) Finland (1959), Moldavian \\
& SSR (1963), Ukrainian SSR (1965) \\
\hline $\mathbf{1 9 7 5}$ & Portugal (1974) \\
\hline $\mathbf{1 9 9 0}$ & $\begin{array}{l}\text { Belgium (1988), Czechoslovakia (1989), Denmark (1987), Italy (1987), Northern } \\
\text { Ireland (1989), Spain (1988), Sweden (1989), Yugoslavia (1989) }\end{array}$ \\
\hline $\mathbf{2 0 0 7}$ & Albania (2003), Belgium (2005), Kosovo (2008), Romania (2008) \\
\hline
\end{tabular}

